\title{
IMPLEMENTASI PEMBELAJARAN TERPADU TERHADAP PERKEMBANGAN KOGNITIF ANAK USIA DINI DI PENDIDIKAN ANAK USIA DINI (PAUD) KABUPATEN MELAWI
}

\author{
Kartini $^{1}$, Waridah ${ }^{2}$ \\ 1,2 Dosen STKIP Melawi \\ Jl. RSUD Melawi km. 04 Kec. Nanga Pinoh Kab. Melawi Kalimantan Barat \\ Kar.kamarudin88@gmail.com, iedhachisulung@yahoo.com
}

\begin{abstract}
Abstrak: Penelitian ini bertujuan untuk mengetahui implementasi pembelajaran terpadu pada pendidikan anak usia dini dan pengaruh pembelajaran terpadu terhadap aspek perkembangan kognitif anak. Penelitian ini adalah Penelitian metode kualitatif dengan dengan pendekatan studi kasus yang mendeskripsikan tentang pemahaman terhadap seseorang diberbagai situasi dimana akan menjadi bagian utama dalam penggambarannya. Teknik pengumpulan data pengamatan peran serta, di mana peneliti berfungsi sebagai instrumen yang tak terpisahkan dengan subjek penelitian untuk melakukan wawancara mendalam, pengamatan terus-menerus dan studi dokumentasi. Analisis data dilakukan dengan model analisis interaktif yang dilakukan melalui empat kegiatan utama yakni: pengumpulan data, reduksi data, penyajian data dan penarikan kesimpulan atau verifikasi. Hasil penelitian menunjukkan Proses pembelajaran terpadu yang dilakukan belum memperlihatkan keterkaitan antara tema dan dilakukan melalui tahapan: kegiatan perencanaan, pelaksanaan, dan evaluasi. Pengaruh pembelajaran terhadap perkem-bangan anak, bidang yang paling menonjol adalah bidang sosial emosional dengan pengenalan "rewards"
\end{abstract}

Kata kunci: pembelajaran terpadu, pendidikan anak usia dini, aspek perkembangan anak

\begin{abstract}
This study aims to investigate: (1) the implementation of integrated learning in early childhood education, and (2) the impact of integrated learning on the aspects of children's cognitive development. The study employed the qualitative method with the phenomenological approach in which the illustration of understanding people in different situation becomes the essential point of the data. The data were collected through participant observations, in which the researcher functioned as the instrument inseparable from the research subjects to carry out in-depth inter-views, continuous observations, and documentation study. The data analysis technique was the interactive analysis model conducted in four main activities, namely data collection, data reduction, data display, and conclusion drawing or verification. The research findings are as follows. (1) The implemented integrated learning process has not shown the relation among themes and was conducted through the stages of activity planning, implementation, and evaluation. In terms of the impact of learning on children's development, the
\end{abstract}


most outstanding areas are the emotional and social areas using the introduction to rewards.

Keywords: integrated learning, early childhood education, aspects of children's cognitive development

A nak adalah individu yang berbeda, unik, dan memiliki karakteristik tersendiri sesuai dengan tahap perkembangannya. Pentingnya mendidik anak sejak usia dini ini dikarenakan masa anak-anak merupakan masa yang sangat peka terhadap pengaruh dari luar, dan pendidikan pada masa anak akan menjadi construk yang berpengaruh terhadap perkembangan anak selanjutnya. Anak yang distimulasi sejak dini akan tampak berbeda dengan anak yang dibiar-kan berkembang tanpa adanya stimulasi di usia dini.

Morisson (1988) berpendapat bahwa Pendidikan Anak Usia Dini adalah pendidikan yang diperuntukan kepada anak dari lahir sampai umur 8 tahun. "Early Childhood Education (ECE) is the education of chlidren from birth to age eight". Pada masa ini sering disebut masa keemasan (golden age), di mana stimulasi seluruh as-pek perkembangan berperan penting untuk tugas perkembangan selanjutnya. Perlu disadari bahwa masamasa awal kehidupan anak merupakan masa terpenting dalam rentang kehidupan seseorang anak. Pada masa ini pertumbuhan otak sedang meng-alami perkembangan yang sangat pesat.

Pada proses pembelajaran, kurikulum yang digunakan dalam Pendidikan Anak Usia Dini bersifat unified, artinya berbagai bidang studi diramu dalam satu tema melalui pembelajaran terpadu. Sesuai dengan pendapat Roopnarine dan Johnson (2011) yang terpenting adalah bahwa apa dan bagaimana dalam pembelajaran harus saling terkait. Untuk belajar dari pengalaman, anak-anak harus terlibat secara langsung dan aktif dengan lingkungan sosial maupun fisik.

Namun pada pelaksanaannya, proses pembelajaran di Pendidikan Anak Usia Dini guru mulai meninggalkan makna dari pem-belajaran terpadu tersebut. Sebagian besar guru terlalu memaksakan kegiatan pembel-ajaran yang lebih menekankan pada pen-capaian tertentu, dan tekanan dari orang tua anak khususnya anak-anak usia 5-6 ta-hun yang merupakan usia persiapan untuk pendidikan ke Sekolah Dasar. Pencapaian yang diinginkan bukan lagi mengenai ke-mampuan anak dalam kemandirian, mau-pun sosialisasi namun lebih kepada kemam-puan pengetahuan membaca, menulis, dan berhitung. 
Sedangkan tujuan sebenarnya pembelajaran matematika untuk anak usia dini adalah belajar berfikir logis dan matematis (logico-mathematical learning) dengan cara menyenangkan dan tidak rumit. Jadi tujuannya bukan agar anak dapat menghitung sampai seratus atau seribu, tetapi memahami bahasa matematis dan penggunaannya untuk berfikir. Piaget dalam Suyanto, (2005).

Banyak orang tua lebih bangga bila anak bisa membaca pada usia 4-5 tahun (usia TK) dibandingkan menguasai kemampuan atau keterampilan hidup yang lebih diperlukan hingga dewasa nantinya. Padahal sekolah unggul adalah sekolah yang memanusiakan manusia, menghargai setiap potensi peserta didik. Chatib (2010) menyatakan bahwa, kemampuan anak untuk memecahkan masalah, berlogika, maupun tidak mudah putus asa sudah jarang sekali terlihat. Anak-anak tersebut seperti kehilangan kepribadiannya dengan mudah mengikuti sikap atau perilaku orang lain.

Masa kanak-kanak yang hanya terjadi satu kali harus benar-benar dipersiapkan agar potensi anak dapat berkembang optimal. Salah satu hal yang harus kita perhati-kan adalah kapan anak belajar, agar anak usia dini tidak merasa dibebani dengan kegiatan belajar tersebut. Pembelajaran pada masa anak usia dini, seharusnya bertujuan untuk mengembangkan semua aspek perkembangan anak terutama kemampuan dasarnya yang akan digunakan pada masa dewasa nantinya. Bukan dengan memberikan beban pembelajaran yang seharusnya belum dikuasai anak. Dalam proses pendidikan anak usia dini, guru harus memahami prinsip yang digunakan dalam kegiatan pembelajaran yang mengembangkan aspek perkembangan anak. Sesuai dengan pendapat Morrisson (1988), Proses perkembangan anak usia dini paling baik melalui cara mem-bebaskan anak untuk berkreasi sebebas-bebasnya, bukan melalui paksaan atau sengaja dibentuk.

Usia 0-8 tahun masih berfikir secara konkrit. Oleh karena itu diharapkan proses pembelajaran yang dilaksanakan senyata mungkin dengan kehidupan anak. salah satu model pembelajaran yang digunakan pada pendidikan anak usia dini yaitu model pembelajaran terpadu dengan tema. Pembelajaran terpadu sendiri merupa-kan suatu sistem pembelajaran yang memungkinkan anak, baik secara individual maupun kelompok, aktif mencari, menggali dan menemukan konsep serta prinsip keilmuan secara holistik, bermakna, dan otentik. Pembelajaran terpadu akan terjadi apabila peristiwa-peristiwa otentik atau eks-plorasi topik/tema menjadi pengendali di dalam kegiatan pembelajaran. Dengan 
ber-partisiasi di dalam eksplorasi tema/peris-tiwa tersebut anak belajar sekaligus mema-hami proses dan isi kegiatan pembelajaran secara serempak.

Apabila dikaitkan dengan tingkat perkembangan anak, pembelajaran terpadu merupakan pendekatan pembelajaran yang memperhatikan dan menyesuaikan pemberian konsep sesuai tingkat perkembangan anak. Pendekatan berangkat dari teori pembelajaran yang menolak drill-system sebagai dasar pembentukan dan struktur intelektual anak. Pembelajaran dengan tema melibatkan kreativitas dalam menyusun satuan pendidikan seperti perencanaan aktivitas disekitar pokok bahasan.

Sesuai yang diungkapkan oleh Eliason and Jenkins, 1994; Machado and Meyer, 1996 (Kostelnik, 1999) tentang pengertian pembelajaran tema, "Theme teaching invol-ves creating an array of educationally sound activities planned around a central idea. These activities are integrated into all aspect of the curriculum and take place within a concentrated time frame, ranging from seve-ral weeks. This creates children's generali-zation of knowledge and skills from one experience to another." Secara tidak lang-sung, tema membantu anak dalam proses pembelajaran secara keseluruhan. Keuntungan dengan menggunakan model pembelajaran terpadu dengan tema sesuai dengan pendapat
Kostelnik (1999). Kelebihan pembelajaran tema bagi anak yaitu, memberikan kesempatan kepada setiap anak untuk mengeksplorasi semua informasi yang dibutuhkan, tema membuat anak memasuki dunia tersebut, nilai lain dari pembelajaran tema adalah menjaga agar kurikulum anak usia dini tetap bervariasi dan menarik, kelompok keterpaduan memberikan kesempatan ke-pada beberapa anak untuk fokus pada fakta-fakta tertentu secara bersama-sama, serta merubah ketertarikan anak dengan menye-suaikan usia.

Dalam pembelajaran terpadu menggunakan tema, akan fokus pada isi tema. Isi pembelajaran menggunakan tema meliputi kesemua informasi yang mengandung relevansi dengan tema. Isi pembelajaran dibu-tuhkan kemampuan seperti mengikuti, mendengarkan, mengamati, mengingat, dan menceritakan kembali. Tema yang paling bagus adalah tema yang yang memiliki kegiatan potensial serta anak dapat melakukan pengalaman pertamanya melalui kegiatan tersebut. Sedangkan ketentuan jumlah tema yang dibahas tidak dapat berbeda-beda, hal tersebut sesuai dengan hasil penelitian Archana V. Hegde dan Deborah J.Cassidy 2009, tentang Kindergaten Teachers' Perspective on Developmentally Appropriate Practice (DAP): A Studi Conducted in Mumbay (India), "Hasil dari 
penelitian kualitatif ini mengemukakan bahwa ada 6 tema yang digunakan dalam proses pem-belajaran. Oleh karena itu banyak sedikit-nya tema ditentukan oleh bagaimana keada-an anak dan kondisi sekolah. Berikut ini contoh tema yang dapat digunakan dalam proses pembelajaran terpadu dengan tema "Binatang",

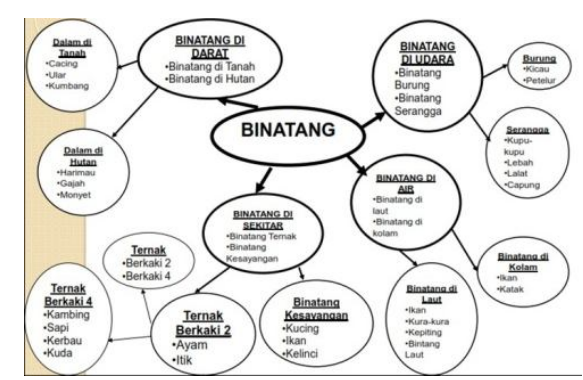

Gambar 1. Tema dengan Model Webbing Topik Tema Binatang

Dengan tema "Binatang" dalam satu hari anak akan diajak untuk mengetahui lebih dalam mengenai Binatang mulai dari apa yang dibutuhkan kucing, bagaimana kucing berkomunikasi, karakteristik Binatang, kela-kuan binatang, dan jenis binatang. Dalam Integrating Curricullum Through Theme Teaching bentuk keterkaitan topik menggunakan model Webbing. Tahapan yang dilakukan dalam pembelajaran yang menggunakan dengan pembelajaran terpadu melalui tema model Webbing antara lain: "Select a theme, Use reference books, As the list grows, Decide the sub topic, Cek your plans, Brainstorm activities, Assign each activities, Make sure the activities represent, Commit your idea,
Check your plan, Explore your plan with children, Adjust your plan, Plan a portion of group time to focus on the theme each day, Make a final check, Create any props, Create thematic atmosphere, Carry out your plan, Assess children's understanding of and interest in the theme, Help the children reflection, Extend the theme, Talk the children about what they want to know more, Establish two way communication with families about the theme, Evaluation your implementation. Helm Harris Judy (Kostelnik, 1999). Tahapan yang dilakukan meliputi perencanaan, pelaksana-an, dan evaluasi.

Pendidik memiliki tanggung jawab memberikan pembelajaran sesuai dengan yang dibutuhkan anak baik secara fisik maupun nonfisik. Secara fisik berupa gedung, kelas, dan arena permainan yang aman dan melatih anak untuk menggunakan peralatan dan perlengkapan yang aman. Anak sebagai individu yang unik memiliki karakteristik yang berbeda, dibutuhkan stimulasi yang sesuai dengan kebutuhannya. Dengan pembelajaran terpadu yang diguna-kan dalam lembaga PAUD diharapkan perkembangan anak akan lebih maksimal.

Setiap anak memiliki perkembangan dan pertumbuhan yang khas, dia bisa berbeda sifat, berbeda kecederungan serta kecepatannya antara satu anak dengan anak 
lainya, berbeda kecederungan serta kecepatanya antara satu anak dengan anak lainya. Menurut Montessori (Roopnarie dan Johnson, 2009) ...pendidikan sebagai sarana "memberikan bantuan pada kehidupan anak, ...membantu proses perkembangan pikiran”. Perkembangan anak akan selalu mengikuti proses pendidikan, dan proses pendidikan akan berfungsi sebagai cara agar perkembangan bisa lebih optimal.

Hurlock (1990), mengungkapkan bahwa perkembangan anak-anak pada umur tertentu meliputi aspek-aspek (1) pertumbuhan fisik, (2) perkembangan motorik, (3) perkembangan bicara, (4) perkembangan emosi, (5) perkembangan sosial, (6) perkembangan bermain, (7) perkembangan kreativitas, (8) perkembangan pengertian, perkembangan moral, (10) peran seks, dan (11) perkembangan kepribadian. Orien-tasi pendidikan pada anak usia dini tidak hanya terbatas pada aspek pengembangan kecerdasan (IQ) semata tetapi juga mencakup aspek-aspek perkembangan yang lebih luas meliputi aspek kognitif, motorik, sosial-emosional-spiritual, dan bahasa, namun dalam penulisan ini akan ditekankan pada aspek kognitif.

\section{Aspek Kognitif}

Aspek Perkembangan kognitif pada anak, menggambarkan bagaimana pemikiran berkembang dan berfungsi sehingga dapat berfikir. Santrock (1997), mengatakan bahwa dunia kognisi anak pra sekolah merupakan sesuatu yang kreatif, bebas dan menyenangkan, pada masa itu imajinasi anak tentang dunia berkembang sangat pesat. Piaget (Goswani, 2011) membagi tahap perkembangan anak menjadi empat tahap yaitu, masa sensorik dari lahir hingga usia 2 tahun, masa praoperasional usia 2 sampai 7 tahun, masa operasional kongkret dari usia 7 sampai 11 tahun, dan masa ope-rasional formal antara usia 11-15 tahun. Pada tahap sensorimotor, anak lebih banyak menggunakan gerak refleks dan indranya untuk berinteraksi dengan ling-kungannya. Dalam tahap ini terdapat tahap: (1) reflexive stage, (2) Primary circular Action, (3) secondary circular reaction, dan (4) coordination of secondary schemata. Pada tahap perkembangan preoperational, menurut pendapat Piaget (Morrisson, 1988) anak yang berkembang adalah anak yang aktif. Hal itu dikarenakan kemampuan anak untuk melakukan sesuatu merupakan refleksi terhadap psikologis dan mentalnya. Oleh karena itu sebagai guru harus bisa memahami anak dengan menyediakan berbagai aktivitas dan kesempatan untuk mengekpresikan hal-hal baru. Setiap kegiatan yang dilakukan oleh anak memberikan kontribusi terhadap perkembangan intelektualnya. Di masa praoperasional tahap 
berfikir anak masih menggunakan simbol atau lebih dikenal dengan benda-benda yang kongkrit sehingga anak akan lebih mudah mema-hami sesuatu bila diperlihatkan secara lang-sung. Dengan simbol anak mampu merepre-sentasikan berbagai hal yaitu, bahasa yang dapat digunakan untuk mendukung dan membantu perkembangan anak, pekerjaan seni dengan berbagai bentuk kegiatan juga dapat membantu anak untuk merepresentasikan keinginan dan idenya, dan pende-katan dengan pengalaman bahasa mem-bantu anak dalam mengekspresikan keinginannya

\section{METODE}

\section{Jenis}

Penelitian ini merupakan penelitian kualitatif dengan pendekatan studi kasus. Pendekatan dalam penelitian, bermakna memahami peristiwa dalam kaitannya dengan orang dalam situasi tertentu.

\section{Waktu dan Tempat}

Penelitian ini dilaksanakan di PAUD Kabupaten Melawi dengan sasar-an pendidikan anak usia 3-6 tahun. Pertimbangan pemilihan PAUD yang ada di Kabupaten Melawi sebagai tempat penelitian, selain didasarkan karena alasan waktu dan sumber yang tersedia, juga didasarkan pada keunikan yang menyediakan proses pembelajaran berdasarkan pada kegiatan dikehidupan se- hari-hari dengan tujuan dapat mengembangkan nilai etika Islam. Waktu penelitian dilakukan selama 9 bulan terhitung sejak bulan Februari sampai dengan bulan November 2018.

\section{Subjek}

Dalam penelitian ini yang dijadikan subjek penelitian adalah semua komponen yang terlibat dalam kegiatan pendidikan anak usia dini di PAUD Kabupaten Melawi, baik penyelenggara, pendidik, orang tua, dan anak.

\section{Teknik Pengumpulan Data}

Pengumpulan data dalam penelitian ini dilakukan dalam tiga tahap. Pada tahap pertama, dilakukan mengumpulkan data secara umum dan luas tentang hal-hal yang menonjol, menarik, penting serta berguna untuk diteliti lebih mendalam. Tahap kedua, eksplorasi pengumpulan data yang dilakukan lebih terarah sesuai dengan fokus penelitian serta mengetahui sumber data atau informan yang kompeten dan mempunyai pengetahuan yang cukup banyak tentang hal yang akan diteliti. Tahap ketiga peneliti melakukan penelitian terfokus yaitu mengembangkan penelitian eksploratif kepada fokus penelitian yaitu pada masalah implementasi pembelajaran terpadu pada pendidikan anak usia dini di PAUD Kabupaten Melawi. Data yang dikumpulkan berdasarkan pada kegiatan: 


\section{Pengamatan}

Dalam penelitian ini tehnik pengamatan digunakan untuk, mengamati, mengumpulkan data dan mendeskripsikan tentang aktivitas pendidik, aktivitas anak, suasana belajar dan bermain, lingkungan belajar, dan sarana bermain.

2. Wawancara

Wawancara untuk menggali informasi dari penyelenggara dan pendidik meliputi pertanyaan tentang, motivasi mendirikan, harapan terhadap anak, usaha yang dilakukan untuk meningkatkan kualitas pembelajaran di PAUD Kabupaten Melawi.

\section{Dokumentasi}

Dokumen-dokumen yang dipelajari meliputi: (1) data mengenai kelembagaan, data penyelenggara, data pendidik, data anak, (2) Data mengenai proses pendidikan seperti rencana program belajar, lembar penilaian, hasil karya anak dan foto-foto kegiatan.

\section{Keabsahaan Data}

Pemeriksaan keabsahan data pada penelitian ini mengikuti kriteria yang diajukan oleh Nasution (1992) dan Moleong (1993) yaitu derajat kepercayaan (credibility), keteralihan (transferability), kebergantungan (dependability) dan kepastian (confirmability).

\section{Analisis Data}

Analisis data pada model ini terdiri dari 4 komponen yang saling berinteraksi yaitu: pengumpulan data, reduksi data, penyajian data, dan penarikan kesimpulan dan verifikasi. Keempat komponen itu merupakan siklus yang berlangsung secara terus menerus antara pengumpulan data reduksi data, penyajian data dan penarikan kesimpulan dan verifikasi data.

\section{HASIL DAN PEMBAHASAN}

\section{Deskripsi Hasil}

\section{Implementasi Pembelajaran Terpadu \\ Perencanaan Pembelajaran}

Kurikulum yang digunakan oleh PAUD Kabupaten Melawi disusun berdasarakan Permen Diknas No. 146 tahun 2014 kurikulum 2013. Dalam pelaksanaan perencanaan kurikulum yang dilakukan di PAUD Kabupaten Melawi terlebih dahulu mengambil kompetensi dasar dari laporan perkembangan hasil belajar. Mencari indikator di RPPM atau di Standar isi Permen Diknas no.137 tahun 2014. Menurunkan kedalam rencana program tahunan, semester, RPPM dan RPPH. Keberhasilan proses pembelajaran tematik dipengaruhi oleh 3 faktor yaitu perencanaan, pelaksanan dan penilaian. Tahapan pelaksanaan pembelajaran tematik di PAUD dimulai dengan adanya identifikasi tema yang akan digunakan dalam pembelajaran. Tema yang sudah 
ditentukan dianalisis dengan kemampuan dasar yang akan dikembangkan dalam proses pembelajaran. Perencanaan yang dibuat dituangkan ke dalam Rencana Pelaksanaan Pembelajaran Mingguan (RPPM) dan Rencana Pelaksanaan Pembelajaran Harian (RPPH). Setiap RPPM mengacu dari program semester yang telah dibuat. Rencana Pelaksanaan Pembelajaran Harian (RPPH) dikembangkan secara rinci dari RPPM yang memuat tema tertentu dari program semster. RPPH disusun berdasarkan tema/subtema atau KD yang dilaksanakan dalam satu atau lebih pertemuan. Dari pencapaian selanjutnya menentukan tema yang akan dibahas, baru ditentukan Rencana Kegiatan Mingguan yang berisi kegiatan pembelajaran bukan lagi indikator pencapaian. Selanjutnya disusun dalam bentuk jaring tema "Spider web" dengan menyesuaikan tema yang diangkat dalam satu minggu tersebut, baru disusun Rencana Kegiatan Harian yang mencakup kegiatan selama sehari sampai dengan evaluasi yang dilakukan serta tindak lanjut yang akan direncanakan.

Selain kegiatan pembelajaran secara terstruktur, pembelajaran yang tidak terstruktur juga direncanakan diawal tahun dalam kegiatan rapat kerja. Kegiatan yang direncanakan antara lain, puncak tema, proses, sains dan AVA yang disesuaikan dengan tema dan tingkatan kelas anak. sedangkan perencanaan kegiatan tahunan meliputi peringatan hari besar keagamaan ataupun hari besar nasional.

Pelaksanaan Pembelajaran

Proses pembelajaran yang dilaksanakan meliputi kegiatan pembukaan, inti, dan penutup. Dalam setiap kegiatan pembelajaran di Kelas Toddler, kelompok Bermain, dan TK membahas 4 tema setiap tahun ajaran.

Kegiatan Pembukaan dimulai dari ikrar yang dilakukan di halaman sekolah dilanjutkan kegiatan morning meeting di dalam kelas. Kegiatan morning meeting me-liputi greeting dan sharing. Selain itu anak membaca doa sehari-hari dan surat pendek, sedangkan dihari Jumat anak akan melaku-kan kegiatan berwudhu dan sholat berjamaah.

Selanjutnya kegiatan inti dimulai dengan kegiatan penjelasan tema secara klasikal. Kegiatan didalam kelas dilakukan dengan moving area, pendidik akan memberikan kesempatan kepada setiap anak untuk memilih setiap area terlebih dahulu. Anak boleh berpindah area setelah menyelesaikan tugas diarea sebelumnya. Kegiatan inti diakhiri dengan makan bersama-sama.

Pada waktu tertentu seperti puncak tema, kegiatan pembelajaran akan menyesuaikan dengan kegiatan yang akan dilakukan. Misalnya puncak tema hewan, 
kegiatan pembelajran dalam satu hari dilakukan di pasar hewan Bantul "Pasthi". Sehingga anak mendapatkan penjelasan secara langsung sub tema yang telah dibahas selama 1 term. Begitu juga dengan kegiatan AVA, melihat film atau video menyesuaikan dengan tema dan dilakukan diantara kegiatan pembel-ajaran yang lain.

\section{Evaluasi Pembelajaran}

Kegiatan evaluasi yang dilakukan di PAUD Kabupaten Melawi, sama dengan lembaga-lembaga pendidikan anak usia dini pada umumnya menggunakan ha-sil penilaian dengan bentuk narasi (cerita) dengan kriteria penilaian BT (Belum Tampak); MB (Mulai Berkembang); BSH (Ber-kembang Sesuai Harapan); dan BSB (Ber-kembang Sangat Baik). Metode yang digu-nakan yaitu: (a) metode observasi, (b) meto-de percakapan, (c) metode porto folio, (d) metode unjuk kerja, (e) metode hasil karya.

Metode penilaian observasi, percakap-an, unjuk kerja, dan hasil karya digunakan di setiap kegiatan pembelajaran. yang nanti-nya akan hasil penilaian akan dimasukkan kedalam rekpitulasi penilaian untuk menen-tukan nilai pada buku laporan perkembang-an setiap term. Untuk penilaian porto folio dilakukan sekali setiap term dengan bidang pengembangan yang berbeda-beda. Penilain ini juga berbeda dengan hasil karya yang telah dihasilkan anak setiap hari.

Kriteria penilaian yang diberikan kepada anak pada hasil karya dengan memberikan tanda bintang mulai dari satu bintang hingga empat bintang. Dan hasil penilaian akan langsung masuk kedalam rekapitulasi nilai anak. Demikian juga dengan metode penilain yang lain seperti unjuk kerja yang sering dilakukan di pagi hari ketiak kegiatan morning meeting, dan penilaian observasi lebih banyak digunakan untuk menilai kegiatan yang mengembangkan sosial emosional anak dan motorik kasarnya.

Proses keterpaduan yang dilaksanakan pada proses pembelajaran terpadu dengan agama sebagai pusatnya masih dengan pembiasaan dan belum memberikan kebermaknaan. Agama adalah hal yang masih abstrak bagi anak usia dini oleh karena itu proses pembelajaran dengan pembiasaan tidak akan memberikan pengaruh apapun terhadap anak. Sebagaimana pendapat Piaget (Morrison, 1988) mengenai tahapan berfikir anak agar proses pembel-ajaran yang masih abstrak bisa diterima, dengan memberikan alasan "reason" atau tujuan "purpose". Proses pembelajaran agama akan lebih bermakna pada anak bila anak dapat melihat secara langsung alasan atau tujuan mempelajari agama. Sebagai contohnya mengucap salam tidak hanya 
dibiasakan di setiap pagi namun berikan alasan kenapa anak harus mengucap salam sehingga anak dapat berfikir bahwa mengucap salam memiliki tujuan bukan pembiasaan. Proses pembelajaran harus lebih menekankan pada pemahaman anak terhadap kegiatan ibadah yang dilakukan, sehingga ketika dewasa nantinya anak memiliki kesadaran sendiri untuk melaksanakan ibadah tersebut mes-kipun tidak dilihat atau dinilai oleh guru dan orang tua.

Kurikulum memang bukan satusatunya hal yang menentukan dalam tujuan pembelajaran, namun memberikan ramburambu terhadap penggunanya agar tidak keluar dari ranah yang telah ditentukan. Dengan mengetahui hal yang harus dilakukan untuk mendukung proses pembelajaran, sebaiknya sebuah kurikulum menekankan pada hal-hal yang sangat penting dan jelas dengan memberikan bekal yang akan digunakan anak untuk menghadapi tantangan di masa depan, sesuai dengan hasil penelitian dari Stig Brostrom, (2006), ”... curriculum emphasing a critical content, which in a much more emphatic way gives the future generation a chance to cope with future challenges. Pembelajaran pada usia dini sebaiknya menekankan pada keterampilan yang akan digunakan sampai anak dewasa nantinya, seperti yang kita ketahui diusia golden age merupakan saat yang tepat untuk memberikan segala hal yang akan bermanfaat karena masa ini tidak akan terulang kedua kalinya.

Dalam tahap perencanaan pembelajaran, alur perencanaan yang dilakukan sebaiknya sistematis dimulai dari penentuan TPP (Tingkat Pencapaian Perkembangan), di uraikan dalam indikator dan kegiatan pembelajaran, kemudian mengkaitkan ke-giatan pembelajaran yang sesuai. Apabila dalam tahap perencanaan tidak dilakukan sebagaimana mestinya maka proses selan-jutnya akan terjadi ketimpangan dalam pe-laksanaan maupun evaluasi pembelajaran. hal tersebut sesuai dengan yang dikemukakan oleh Worthen and Sanders, (1973) "planning is essential in systematic evaluation studies. Without rigorous outline, evaluation studies can easily proceed without direction, and hence, without any end point."

Proses pembelajaran yang terpadu yang dilaksanakan belum mengaitkan kegiatan pembelajaran ke dalam aspek perkembangan karena dalam proses perencanaan yang dilakukan belum sesuai dengan sistematika yang seharusnya dilakukan. Kegiatan pembelajaran masih terpisah dengan aspek perkembangan yang ingin dikembangkan oleh pendidik. Pembelajaran dengan setting area di dalam kelas pendidikan anak usia dini, ter-bukti lebih sesuai dan tempat yang responsif 
untuk bertemunya kebutuhan anak usia dini. Area mengikuti aktivitas dan tujuan dibangunnya lingkungan belajar oleh orang dewasa sesuai dengan instruksi untuk mengembangkan perkembangan akan keterampilan yang utama dan kemampuan pada anak. Tujuan menggunakan area diharapkan mampu menyatukan tema yang dibahas salam satu hari tersebut tidak terpisah satu dengan yang lain mengingat cara anak usia dini yang masih berfikir secara holistic atau menyeluruh. Namun dalam proses pembelajarannya area masih mengikat kegiatan anak, kegiatan di area masih menyesuaikan dengan nama area tersebut.

Hal tersebut dikaji dari pendapat Kostelnik, (1999), yang menyatakan tentang karateristik dalam pembelajaran anak usia dini dengan area yang efektif. ..."Center-based activity can be much more successful when teachers take time to introduce children encounter them." Area yang ada di kelas juga tidak terpaku sesuai dengan namanya saja, “...could be used to address the cognitive domain one day, the language domain another day, and the social domain on yet another". Diharapkan guru pendidikan anak usia dini mampu lebih kreatif dalam memanfaatkan area yang telah tersedia, menggunakan berbagai permainan yang telah ada didalamnya tanpa harus terpaku memberikan lembar kerja atau tugas kepada anak yang tidak sesuai dengan tema yang dibahas bersama.

Sedangkan pada proses evaluasi dalam kegiatan penilaian tersebut belum digunakan rubrik penilaian sehingga proses evaluasi belum objektif. Oleh karena itu penilaian yang diberikan belum bisa mewakili hasil perkembangan anak selama pro-ses pembelajaran. Sebagaimana pendapat dari Kostelnik, (1999), mengenai ben-tuk penilaian dengan menggunakan tema metode yang digunakan antara lain "Anec-dotal record, Frequency counts and charts, Checklist, Rating scales, Participation chart”.

Hal tersebut diperkuat oleh hasil penelitian dari Hannah Nissen dan Carol J. Hawkins "Observasing and Supporting Young Chlidren's Social Competence“, yang mengemukakan metode penilaian yang dilakukan pada proses pembelajaran anak usia dini khususnya aspek perkembangan sosial yaitu Anecdotal record, Anecdotal record, dan video. Dengan bentuk penilaian yang menekankan pada aspek perkem-bangan dan pembelajaran anak, berdasar pada peristiwa nyata, penampilan anak, berhubungan dengan instruksi, fokus pada tujuan pembelajaran, melibatkan semua konteks pembelajaran, gambaran umum akan kemampuan belajar anak, dan bentuk kolaborasi lingkungan anak akan terlihat 
perkembangan anak yang lebih jelas. Bentuk penilaian yang diberikan kepada anak sama dengan lembaga pendidik-an anak usia dini yang lain menggunakan narasi namun dalam menilai belum tersedia pedoman instrument penilaian. Nilai yang diberikan belum memperlihatkan objektivitas, sehingga setiap kriteria nilai anak akan berbeda-beda.

\section{Pengaruh Pembelajaran Terpadu}

Perkembangan Kognitif

Pada aspek perkembangan kognitif anak di PAUD Kabupaten Melawi sebagaimana teori Piaget (Morisson, 1988) anak memasuki masa preoperational, perkembangan kogntif yang paling menonjol adalah egosentris. Ego sentrisme, yaitu anak memandang dunia luar dari sudut pandang subjeknya, sikap ini terlihat dominan dialami oleh anak usia Kelompok Bermain.

Apabila perkembangan kognitif yang dialami oleh anak, dikaji dari pendapat John Piaget (Morrison, 1976), anak usia dini 2-7 tahun memasuki tahap berfikir secara "preoperational" egosentris memang hal yang biasa dialami oleh anak usia 3 tahun dan akan berkurang bila memasuki usia 4 tahun. Namun sebagai pendidik, tetap memiliki kewajiban untuk mengembangkan kemampuan anak agar egosentrisnya dapat berkembang lebih maksimal.
Pada masa preoperasional sebagaimana teori John iaget dalam (Morrison, 1988,) anak belum mampu membeda-kan massa, kualitas, dan volum bila ditempatkan pada tempat, ukuran, serta dimensi yang berbeda. Proses pembelajaran yang lebih maksimal akan diperoleh hasilnya bila anak mengenal melalui hal nyata dan kegiatan yang dilakukan dengan suasana menyenangkan. Dengan proses pembelajaran yang telah berlangsung, perkembangan kognitif yang telah dicapai anak antara lain pengenalan warna, konsep bilangan, simbol, posisi, dan waktu. Kegiatan yang dilakukan untuk mengembangkan kemampuan anak, terkait dengan pengenalan konsep simbol, bilangan, warna, posisi, dan waktu lebih ba-nyak dilakukan dengan mengerjakan lembar kerja atau worksheet dan sharing.

Kegiatan sharing adalah kegiatan yang dilakukan untuk perkembangan anak agar egosentris berkurang. Anak mulai diminta untuk menceritakan kegiatannya di hari libur atau kegiatan dirumah didepan teman-temannya. Setelah anak selesai bercerita, pendidik akan memandu anak untuk meng-ungkapkan cerita dari sudut pandang yang berbeda dengan pertanyaan. Teman-teman-nya juga diberikan kesempatan untuk ber-tanya kepada anak yang bercerita, sehingga anak akan belajar 
untuk melihat sudut pandang cerita dari pendidik dan teman sebayamya.

Perkembangan anak di aspek kognitif akan lebih berkembang bila anak juga diajak untuk mengenal simbol-simbol, mulai dari hal yang paling sederhana di sekitar anak. selain itu hasil karya anak tidak hanya ber-henti setelah anak selesai mengerjakan, pendidik bisa meminta anak untuk men-ceritakan apa yang telah digambar atau dibuat didepan kelas. Sehingga anak akan belajar untuk memahami sesuatu dari sudut pandang yang berbeda. Dengan pertanyaan yang akan menstimulus anak untuk mene-mukan konsep akan sesuatu lebih men-dalam.

\section{SIMPULAN}

Proses pembelajaran yang telah dilaksanakan dilakukan dengan melalui tahapan perencanaan, pelaksanaan, dan evaluasi kegiatan pembelajaran. Dalam proses perencanaan telah terlihat alur kurikulum dengan memadukan Kurikulum Pengembangan Pribadi yang dimiliki dengan standar isi Permen Diknas No. 146 tahun 2014. Pembelajaran yang dilakukan meng-gunakan tema di setiap termnya dan dipadukan dengan kegiatan di luar struktur kurikulum. Dalam proses pembelajaran kegiatan yang dilakukan masih dalam kegiatan pembiasaan. Dalam proses evaluasi metode penilaian menggunakan criteria BM, MB, BSH, dan BSB dengan menggunakan tanda bintang dan langsung masuk kedalam reapitulasi nilai.

Pada aspek perkembangan anak, kegiatan yang dilakukan untuk menstimulus-nya yaitu, kegiatan sharing di pagi hari untuk pengembangan aspek kognitif anak, antri dan berbagi mainan maupun makanan untuk perkembangan sosial emosional. Sedangkan perkembangan bahasa dengan kegiatan mengenal keaksaraan, dan kegiat-an senam di pagi hari, kegiatan bermain setelah ikrar, serta kegiatan gerak dan lagu diakhir tahun dilakukan untuk pengem-bangan motorik kasar anak.

Berdasarkan hasil dan temuan yang diperoleh serta dengan memperhatikan ke terbatasan penelitian, saran yang disampaikan adalah sebagai berikut: (1) perlunya penekanan akan kebermaknaan kegiatan yang menekankan kepda tujuan serta alasan akan kegiatan pembelajaran yang dilakuakn oleh anak. (2) Pengembangan kemampuan anak akan lebih maksimal dengan variasi kegiatan dan media yang digunakan dan disesuiakan denga tahap perkembanga anak.

\section{DAFTAR PUSTAKA}

Goswami, U. 2010. The Willey Blackwell Handbook ofChildhood Cognitive Development. Second Edition. New York: A John Willey \& Sons, Ltd. 
Hedge, A. V. \& Cassidy, D. J. 2009. “Kindergaten Teachers' Perspectives on Developmentally Appropriate Practices (DAP): A Study Conduted in Mumbai (India)". Journal of Research in Childhood Education, Spring 2009, Vol. 23, No. 3, Research Library, pg. 367.

Hurlock, E.B. 1990. Psikologi Perkembangan Suatu Pendekatan Sepanjang Rentang Kehidupan. Edisi Ketiga. Jakarta: Erlangga.

Kostelnik, Marjorie J. Soderman, Anne K. \& Whiren, Alice Phipps. 1999. Develop-mentally Appropriate Curriculum. Best Practices in Early Childhood Education. New Jersey: Prentice-Hall, Inc.

Morisson, G. S. 1988. Early Childhood Education Today. Fourth

Edition. Columbus: Merrill

Publishing Company.

NAEYC. 2009. Developmentally Appropriate Practice in Early Childhood Program Serving Children from Birth through Age 8. A Position statement of the National Association for the Educational of Young Children. Adopted. 2009.

Roopnarine, J. L. \& Johnson, J. E. 2011. Pendidikan Anak Usia Dini. Dalam berbagai pendekatan. (Terje-mahan Sari Narulita).
Santrock, J. W. 1980. Life-Span Development. Perkembangan Masa Hidup. Edisi Ke lima. Jakarta: Erlangga. 